\title{
Aktivitas Anti-Mycobacterium tuberculosis Kombinasi (-)-Epigallocatechin- Gallate (EGCG) dan Obat Antituberkulosis Lini Pertama
}

\section{Anti-Mycobacterium tuberculosis Activity of (-)-Epigallocatechin-gallate (EGCG) and First-line Antituberculosis Drugs Combination}

\author{
Anggita Mirzautika $^{I^{*}}$, Isnaeni ${ }^{2}$, Djoko Agus Purwanto ${ }^{2}$ \\ ${ }^{1}$ Balai Penelitian dan Pengembangan Kesehatan Magelang, Magelang, Jawa Tengah, Indonesia \\ ${ }^{2}$ Departemen Kimia Farmasi, Fakultas Farmasi, Universitas Airlangga, Surabaya, Jawa Timur, Indonesia \\ *E-mail: anggita.mz@gmail.com
}

Diterima: 24 April 2019

Direvisi: 16 Oktober 2019

Disetujui: 13 Februari 2020

\begin{abstract}
Abstrak
Tuberkulosis merupakan masalah kesehatan global, bahkan terdapat peningkatan kasus multidrug-resistant tuberculosis di dunia. Oleh karena itu, diperlukan penelitian yang dapat menemukan obat antituberkulosis (OAT) yang lebih efektif untuk pengobatan tuberkulosis. Pada penelitian ini, efek (-)-epigallocatechin-gallate (EGCG) dari daun teh (Camellia sinensis) yang dikombinasikan dengan OAT lini pertama akan diamati dengan tujuan untuk mengetahui apakah EGCG memiliki aktivitas antituberkulosis dan dapat meningkatkan potensi OAT lini pertama secara in vitro. Aktivitas antituberkulosis EGCG ditentukan dengan metode broth dilution menggunakan media Middlebrook 7H9 pada konsentrasi 50, 100, 150, dan 200 ppm, kemudian ditentukan potensi OAT lini pertama sebelum dan setelah dikombinasikan dengan EGCG. Hasil penelitian menunjukkan aktivitas antituberkulosis EGCG pada konsentrasi $50 \mathrm{ppm}$ dan $100 \mathrm{ppm}$ sebesar $80 \%$, konsentrasi $150 \mathrm{ppm}$ sebesar 90\%, dan konsentrasi 200 ppm sebesar 100\%. Aktivitas OAT lini pertama sebelum dikombinasikan dengan EGCG tercapai $\geq 90 \%$ pada konsentrasi rifampisin $5 \mathrm{ppm}$, isoniazid $0,5 \mathrm{ppm}$, pirazinamid $50 \mathrm{ppm}$, dan etambutol $5 \mathrm{ppm}$. Sedangkan setelah dikombinasikan dengan EGCG, potensi masing-masing obat tersebut meningkat ditandai dengan aktivitas antituberkulosis tercapai $\geq 90 \%$ pada konsentrasi yang lebih rendah, yaitu rifampisin 0,5 ppm, isoniazid $0,25 \mathrm{ppm}$, pirazinamid $20 \mathrm{ppm}$, dan etambutol $2 \mathrm{ppm}$. Hasil tersebut menunjukkan bahwa potensi masing-masing OAT lini pertama meningkat setelah dikombinasikan dengan EGCG, serta EGCG memberikan efek potensiasi. Kesimpulan, EGCG dapat meningkatkan aktivitas OAT lini pertama.
\end{abstract}

Kata kunci: (-)-Epigallocatechin-gallate; Obat antituberkulosis lini pertama; Anti-Mycobacterium tuberculosis; Efek sinergis

\begin{abstract}
Tuberculosis is a global health problem, and there is even an increase in cases of multidrug-resistant tuberculosis in the world. Therefore, research is needed that can find new anti-tuberculosis drugs (OAT) that are more effective for tuberculosis treatment. In this study, the effect of (-)-epigallocatechin-gallate (EGCG) of tea leaves (Camellia sinensis) combined with the first-line OAT will be observed, in order to find out whether EGCG has anti-tuberculosis activity and can increase the potential of first-line OAT in-vitro. The antituberculosis activity of EGCG was determined by broth dilution method using Middlebrook 7 H9 media at concentration of 50,100, 150, dan $200 \mathrm{ppm}$, then the potential of first-line OAT before and after combined with the EGCG was observed. The results showed that the activity of EGCG at concentration $50 \mathrm{ppm}$ and $100 \mathrm{ppm}$ could inhibit the Mycobacterium tuberculosis growth by 80\%, at concentration $150 \mathrm{ppm}$ by $90 \%$, and at concentration 200 ppm by 100\%. First-line OAT activity before combined with EGCG was $\geq 90 \%$ at 5 ppm rifampicin, $0.5 \mathrm{ppm}$ isoniazid, $50 \mathrm{ppm}$ pyrazinamide, and $5 \mathrm{ppm}$ ethambutol. Whereas after combined with $E G C G$, the potential of each drug increased, marked by anti-tuberculosis activity achieved $\geq 90 \%$ at lower concentrations, i.e. rifampicin 0.5 ppm, isoniazid 0.25 ppm, pyrazinamide 20 ppm, and ethambutol 2 ppm. These results indicated that the potential of each first-line OAT increases after being combined with EGCG, and EGCG has potentiation effect when combined with those drugs. In conclusion, EGCG can increase the first-line OAT activity.
\end{abstract}

Keywords: (-)-Epigallocatechin-gallate; First-line antituberculosis drugs; Anti-Mycobacterium tuberculosis; Synergism effect 


\section{PENDAHULUAN}

Tuberkulosis (TB) merupakan masalah kesehatan global. Berdasarkan data dari World Health Organization (WHO), terdapat 8,6 juta kasus TB baru pada tahun 2012 dan sebanyak 1,3 juta meninggal dunia. ${ }^{1}$ Pada tahun 2017, kasus TB yang tercatat di Indonesia ada sejumlah 442.000. ${ }^{2}$ Permasalahan lain yang timbul kemudian adalah multidrug-resistance TB (MDR-TB), yaitu Mycobacterium tuberculosis (M. tuberculosis) yang telah resisten terhadap sedikitnya dua obat antituberkulosis (OAT) yang paling efektif, yaitu isoniazid (INH) dan rifampisin (RIF). ${ }^{3}$ Dari 442.000 kasus TB di Indonesia, diperkirakan ada 8.60015.000 kasus MDR-TB. ${ }^{2}$ Pengobatan yang tidak adekuat merupakan salah satu faktor resiko MDR-TB. Penyebab pengobatan yang tidak adekuat antara lain lambatnya diagnosis, terlambat diketahui adanya resistensi obat, regimen kemoterapi yang tidak sesuai, penyediaan obat yang tidak adekuat dan tidak teratur, serta kepatuhan yang kurang, baik dari pihak pasien maupun klinisi. ${ }^{4}$

Pengobatan yang tidak adekuat merupakan salah satu faktor kegagalan dalam terapi, namun ada beberapa faktor lain ikut berperan yaitu kualitas obat yang kurang bagus, kegagalan pengobatan, perawatan penyakit sebelumnya, infeksi HIV dan penyakit diabetes. Dari hal tersebut, prediktor paling kuat untuk timbulnya kasus MDR-TB yaitu karena kesalahan dalam manajemen TB seperti penggunaan single drug untuk pengobatan TB, regimen yang gagal, kegagalan mengidentifikasi resistensi awal, inisiasi regimen yang tidak adekuat menggunakan OAT lini pertama, serta variasi bioavailabilitas OAT. ${ }^{5}$

Penelitian intensif diperlukan untuk mencapai pengobatan TB yang efektif, memperpendek durasi pengobatan, dan meminimalkan efek samping pengobatan TB. (-)-Epigallocatechin-gallate (EGCG) merupakan senyawa polifenol yang ditemukan dalam teh hijau (Camellia sinensis), dan dilaporkan memiliki efek antimikroba. Penelitian sebelumnya tentang aktivitas antimikroba dari ekstrak teh dapat terjadi karena adanya ikatan kuat antara muatan negatif pada EGCG dengan muatan positif pada lapisan lipid bilayer bakteri Gram-positif. Senyawa katekin berpartisi ke dalam membran lipid bilayer yang menyebabkan struktur dan fungsi sel bakteri menurun, sehingga mengakibatkan kematian sel bakteri. ${ }^{6}$ Penelitian yang dilakukan Anand dkk menunjukkan bahwa komponen utama polifenol teh hijau, yaitu EGCG memiliki kemampuan inheren untuk menurunkan transkripsi gen Tryptophan-Aspartate-containing Coat Protein (TACO) dalam makrofag manusia melalui kemampuannya menghambat faktor transkripsi SP1. Penurunan ekspresi gen TACO oleh EGCG dibarengi dengan penghambatan hidup mycobacterium dalam makrofag. ${ }^{7}$

EGCG mempunyai fungsi lain yaitu sebagai antioksidan yang dapat berperan menghambat pertumbuhan $M$. tuberculosis. Induksi dan aktivasi reactive oxygen species (ROS) dan sitokin proinflammatory TNF- $\alpha$ (tumor necrosis factor) berperan penting dalam proliferasi M. tuberculosis pada sel host (human monocytes). ${ }^{8}$ Fatima dkk telah melakukan penelitian secara in vitro dan menunjukkan berdasarkan potensi antioksidannya, EGCG dapat menghambat jalur ROS dan reactive nitrogen intermediates (RNI), selain itu EGCG juga memberikan hasil yang lebih baik dalam penghambatan ekspresi gen TNF- $\alpha$ dan MTB 85B dibandingkan OAT lini pertama lain. ${ }^{9,10}$

EGCG mempunyai aktivitas sebagai antituberkulosis, sehingga jika dikombinasikan dengan OAT lini pertama akan dapat meningkatkan potensi OAT tersebut. Kombinasi EGCG dengan OAT lini pertama dapat meningkatkan potensi antituberkulosis, maka pengobatan TB akan lebih efektif dan mencegah resiko resistensi obat. 


\section{METODE}

Metode yang digunakan pada penelitian ini menggunakan metode broth dilution dengan media Middlebrook 7H9 untuk menentukan aktivitas antituberkulosis, mengacu pada metode standar yang digunakan untuk menguji aktivitas antituberkulosis di Institute of Tropical Disease, Universitas Airlangga, Surabaya, dan sesuai dengan metode yang digunakan pada penelitian PeñuelasUrquides dkk dengan sedikit modifikasi. ${ }^{11}$

Tahap pertama yang dilakukan pada yaitu menentukan aktivitas antituberkulosis masing-masing OAT lini pertama dan EGCG dengan metode broth dilution menggunakan media Middlebrook 7H9, kemudian diukur optical densityyang dihasilkan dengan Nephelometer.

Dipilih metode broth dilution tersebut karena pada penelitian yang telah dilakukan oleh Chen dkk menggunakan metode broth dilution dengan media Middlebrook 7H9 untuk menentukan aktivitas senyawa yang menghambat $M$. tuberculosis. Klancnik dkk juga menyarankan untuk evaluasi penentuan aktivitas antibakteri dari ekstrak tanaman sebaiknya menggunakan metode broth dilution. $^{12,13}$

Penentuan aktivitas OAT lini pertama dilakukan untuk mengevaluasi potensi OAT terhadap $M$. tuberculosis $\mathrm{H} 37 \mathrm{Rv}$ sebelum dikombinasikan dengan EGCG, sedangkan observasi aktivitas antituberkulosis EGCG dilakukan untuk menentukan konsentrasi EGCG yang akan dikombinasikan dengan OAT.

Angka pertumbuhan adalah selisih optical density masing-masing campuran uji tiap waktu terhadap hari ke-0, sedangkan persentase hambatan pertumbuhan adalah persentase selisih angka pertumbuhan masing-masing campuran uji terhadap kontrol positif dibandingkan angka pertumbuhan kontrol positif. Obat anti-tuberkulosis lini pertama dan EGCG memiliki aktivitas dalam menghambat pertumbuhan $M$. tuberculosis H37Rv jika masing-masing mampu menghasilkan hambatan pertumbuhan $\geq$ $90 \%$ terhadap kontrol positif. ${ }^{14}$

\section{Alat dan bahan}

Bahan yang digunakan yaitu standar EGCG (kemurnian 98\%) dari Xi'an Rongsheng Biotechnology Co.,Ltd., China, standar isoniazid (INH) dari Second Pharma Co., Ltd., standar rifampisin (RIF) dari Shenyang Antibiotic Manufacturer, standar pirazinamid (PZA) dari DIFC Co., Ltd., standar etambutol (EMB) dari LUPIN Ltd., Dimethyl Sulfoxide (DMSO) p.a., Dimethyl Formamide (DMF) p.a., Aquadest, media Middlebrook 7H9 (Difco ${ }^{\mathrm{TM}}$ ), media Lowenstein-Jensen (Difco $^{\mathrm{TM}}$ ). M. tuberculosis H37Rv ATCC strains diperoleh dari Institute of Tropical Disease, Universitas Airlangga Surabaya.

Alat yang digunakan yaitu Bio Safety Cabinet (Lab Gard), autoklaf (Biolab), inkubator (Memmert), dan Nephelometer (BD Phoenix Spec).

\section{Pembuatan inoculum dan larutan baku}

Inokulum dibuat dari $M$. tuberculosis strain H37Rv yang telah ditumbuhkan pada media Lowenstein-Jensen, lalu dimasukkan ke dalam tabung berisi media broth Middlebrook 7H9, selanjutnya kekeruhannya dibandingkan dengan standar McFarland 0,5.

Larutan baku induk INH dan EMB dibuat dalam pelarut akuades, RIF dibuat dalam pelarut DMF, PZA dibuat dalam pelarut DMSO, dan EGCG dibuat dalam pelarut akuades panas. Larutan baku induk diencerkan ke dalam media broth Middlebrook 7H9 untuk membuat larutan

Persentase hambatan $=\frac{\text { Angka pertumbuhan kontrol positif }- \text { angka pertumbuhan campuran uji }}{\text { Angka pertumbuhan kontrol positif }} \times 100 \%$ 
baku kerja INH, EMB, RIF, PZA dan EGCG dengan kadar yang diinginkan. ${ }^{11}$

\section{Penentuan aktivitas antituberkulosis OAT lini pertama dan EGCG}

Campuran uji terdiri dari larutan baku kerja OAT dan EGCG dipipet sebanyak 1 $\mathrm{mL}$, kemudian dimasukkan ke dalam tabung uji (kuvet) yang telah berisi $4 \mathrm{~mL}$ media Middlebrook $7 \mathrm{H} 9$ yang mengandung $0,5 \mathrm{~mL}$ inokulum $M$. Tuberculosis strain $\mathrm{H} 37 \mathrm{Rv}$ setara dengan McFarland $0,5 \quad\left(1,5 \quad\right.$ x $\left.10^{8} \quad \mathrm{cfu} / \mathrm{mL}\right)$, dicampur hingga homogen.

Kontrol positif dibuat dengan menambahkan $0,5 \mathrm{~mL}$ inokulum $M$. Tuberculosis strain $\mathrm{H} 37 \mathrm{Rv}$ yang setara dengan McFarland 0,5 (1,5 x $\left.10^{8} \mathrm{cfu} / \mathrm{mL}\right)$ ke dalam tabung uji (kuvet) yang telah berisi 4,5 mL media Middlebrook 7H9, dan dicampur homogen. Setiap sampel dilakukan replikasi sebanyak 2 kali (duplo).

Media Middlebrook $7 \mathrm{H} 9$ (kontrol negatif), kontrol positif, dan campuran larutan uji, masing-masing diinkubasi pada suhu $37^{\circ} \mathrm{C}$ selama 28 hari. Pengamatan optical density pada tiap sampel dilakukan dengan menggunakan Nephelometer. ${ }^{11}$

\section{Penentuan aktivitas antituberkulosis kombinasi OAT lini pertama dan EGCG}

Konsentrasi EGCG yang dikombinasikan dengan masing-masing OAT lini pertama yaitu 150 ppm, merupakan konsentrasi dengan aktivitas antituberkulosis EGCG mencapai 90\%.. Campuran uji terdiri dari larutan kombinasi OAT dan EGCG dengan konsentrasi OAT yang berbeda. Larutan
OAT dan EGCG masing-masing dipipet sebanyak $1 \mathrm{~mL}$, kemudian dimasukkan ke dalam tabung uji yang telah berisi $3,5 \mathrm{~mL}$ media Middlebrook $7 \mathrm{H} 9$ yang mengandung $0,5 \mathrm{~mL}$ inokulum $M$. tuberculosis strain $\mathrm{H} 37 \mathrm{Rv}$ setara dengan McFarland $0,5 \quad\left(1,5 \quad\right.$ x $\left.10^{8} \quad \mathrm{cfu} / \mathrm{mL}\right)$, selanjutnya dicampur homogen. Masingmasing sampel dilakukan replikasi sebanyak 2 kali (duplo).

Kontrol obat dibuat dengan memipet larutan baku kerja OAT pada konsentrasi yang digunakan sebanyak $1 \mathrm{~mL}$ dan kontrol uji dengan memipet larutan baku kerja EGCG 150 ppm sebanyak $1 \mathrm{~mL}$, kemudian setiap sampel dimasukkan ke dalam tabung uji (kuvet) yang telah berisi $4 \mathrm{~mL}$ media Middlebrook $7 \mathrm{H} 9$ yang mengandung $0,5 \mathrm{~mL}$ inokulum $M$. Tuberculosis strain H37Rv setara dengan McFarland 0,5 (1,5 x $\left.10^{8} \mathrm{cfu} / \mathrm{mL}\right)$, lalu dicampur homogen. Tiap sampel dilakukan replikasi sebanyak 2 kali (duplo).

Kontrol positif dibuat sama seperti pada penentuan aktivitas antituberkulosis sebelumnya. Media Middlebrook 7H9 (kontrol negatif), kontrol positif, kontrol obat, kontrol uji dan campuran uji, masingmasing diinkubasi pada suhu $37^{\circ} \mathrm{C}$ selama 28 hari. Pengamatan optical density masing-masing sampel dilakukan menggunakan nephelometer. ${ }^{11}$

\section{HASIL DAN PEMBAHASAN}

Obat anti-tuberkulosis lini pertama dan EGCG memiliki aktivitas dalam menghambat pertumbuhan $M$. tuberculosis H37Rv jika masing-masing mampu menghasilkan hambatan pertumbuhan $\geq$ $90 \%$ terhadap kontrol positif. ${ }^{14}$

Tabel 1. Rerata angka pertumbuhan dan persentase hambatan pertumbuhan M. tuberculosisoleh EGCG $(\mathrm{n}=2)$

\begin{tabular}{lcc}
\hline \multicolumn{1}{c}{ Sampel } & $\begin{array}{c}\text { Angka pertumbuhan } \\
(\mathbf{N T U})\end{array}$ & $\begin{array}{c}\text { Hambatan pertumbuhan } \\
(\mathbf{\%})\end{array}$ \\
\hline Kontrol positif & $0,10 \pm 0,007$ & $0 \pm 0,007$ \\
EGCG 200 ppm & $0,00 \pm 0,000$ & $100 \pm 0,000$ \\
EGCG 150 ppm & $0,01 \pm 0,007$ & $90 \pm 0,007$ \\
EGCG 100 ppm & $0,02 \pm 0,007$ & $80 \pm 0,007$ \\
EGCG 50 ppm & $0,02 \pm 0,007$ & $80 \pm 0,007$ \\
\hline \multicolumn{2}{l}{ EGCG $=(-)$-Epigallocatechin-gallate }
\end{tabular}


Data awal yang yang diperoleh dalam riset ini adalah rerata angka pertumbuhan dan persentase hambatan pertumbuhan $M$. tuberculosis oleh EGCG (Tabel 1). Konsentrasi EGCG yang mampu menghasilkan hambatan pertumbuhan $90 \%$ adalah 150 ppm, yang selanjutnya digunakan untuk kombinasi dengan OAT lini pertama. Rerata angka pertumbuhan dan persentase hambatan pertumbuhan $M$. tuberculosis oleh masing-masing OAT sebelum dan setelah dikombinasikan dengan EGCG menunjukkan bahwa potensi masing-masing OAT lini pertama meningkat jika dikombinasikan dengan EGCG. Hal ini ditandai dengan konsentrasi OAT yang mampu menghasilkan hambatan pertumbuhan $\geq 90 \%$ setelah dikombinasikan dengan EGCG 150 ppm lebih rendah dari pada konsentrasi OAT sebelum dikombinasikan (Tabel 2,3,4,5).

Tabel 2. Rerata persentase hambatan pertumbuhan M. tuberculosis oleh RIF sebelum dan setelah kombinasi dengan EGCG 150 ppm $(n=2)$

\begin{tabular}{|c|c|c|}
\hline \multirow[t]{2}{*}{ Konsentrasi } & $\begin{array}{c}\text { Hambatan } \\
\text { pertumbuhan } M . \\
\text { tuberculosis }(\%)\end{array}$ & $\begin{array}{c}\text { Hambatan pertumbuhan } M . \\
\text { tuberculosis(+ EGCG } 150 \text { ppm) } \\
(\%)\end{array}$ \\
\hline & RIF & RIF \\
\hline $20 \mathrm{ppm}$ & $100 \pm 0,000$ & - \\
\hline 10 ppm & $100 \pm 0,000$ & - \\
\hline $5 \mathrm{ppm}$ & $\underline{90} \pm 0,014$ & $90 \pm 0,000$ \\
\hline $1 \mathrm{ppm}$ & - & $90 \pm 0,000$ \\
\hline $0,5 \mathrm{ppm}$ & - & $\underline{90} \pm 0,000$ \\
\hline $0,25 \mathrm{ppm}$ & - & $70 \pm 0,007$ \\
\hline $0,2 \mathrm{ppm}$ & $80 \pm 0,000$ & - \\
\hline
\end{tabular}

Tabel 3. Rerata persentase hambatan pertumbuhan $M$. tuberculosisoleh INH sebelum dan setelah kombinasi dengan EGCG 150 ppm $(n=2)$

\begin{tabular}{lcc}
\hline Konsentrasi & $\begin{array}{c}\text { Hambatan } \\
\text { pertumbuhan } \\
\text { tuberculosis }(\%)\end{array}$ & $\begin{array}{c}\text { Hambatan pertumbuhan } \boldsymbol{M} . \\
\text { tuberculosis(+ EGCG 150 ppm) } \\
(\boldsymbol{\%})\end{array}$ \\
\cline { 2 - 3 } $5 \mathrm{ppm}$ & $\mathbf{I N H}$ & $\mathbf{I N H}$ \\
$1 \mathrm{ppm}$ & $100 \pm 0,000$ & - \\
$0,5 \mathrm{ppm}$ & $100 \pm 0,000$ & $90 \pm 0,000$ \\
$0,25 \mathrm{ppm}$ & $\underline{90} \pm 0,000$ & $\underline{90} \pm 0,000$ \\
$0,1 \mathrm{ppm}$ & $80 \pm 0,000$ & $\mathbf{8 0} \pm 0,014$ \\
\hline INH = Isoniazid; EGCG $=(-)$-Epigallocatechin-gallate &
\end{tabular}

Tabel 4. Rerata persentase hambatan pertumbuhan $M$. tuberculosisoleh PZA sebelum dan setelah kombinasi dengan EGCG 150 ppm $(n=2)$

\begin{tabular}{lcc}
\hline \multirow{2}{*}{ Konsentrasi } & $\begin{array}{c}\text { Hambatan } \\
\text { pertumbuhan } \boldsymbol{M} . \\
\text { tuberculosis }(\%)\end{array}$ & $\begin{array}{c}\text { Hambatan pertumbuhan } \mathbf{~} \\
\text { tuberculosis(+ EGCG 150 ppm) } \\
(\mathbf{\%})\end{array}$ \\
\cline { 2 - 3 } $100 \mathrm{ppm}$ & $100 \pm 0,000$ & $\mathbf{\text { PZA }}$ \\
$50 \mathrm{ppm}$ & $\underline{90} \pm 0,000$ & - \\
$25 \mathrm{ppm}$ & $80 \pm 0,007$ & $90 \pm 0,000$ \\
$20 \mathrm{ppm}$ & $70 \pm 0,000$ & $\underline{90} \pm 0,000$ \\
$10 \mathrm{ppm}$ & - &
\end{tabular}




\section{Tabel 5.Rerata persentase hambatan pertumbuhan $M$. tuberculosisoleh EMB sebelum dan setelah kombinasi dengan EGCG 150 ppm $(n=2)$}

\begin{tabular}{lcc}
\hline \multirow{2}{*}{ Konsentrasi } & $\begin{array}{c}\text { Hambatan } \\
\text { pertumbuhan } \boldsymbol{M} . \\
\text { tuberculosis }(\%)\end{array}$ & $\begin{array}{c}\text { Hambatan pertumbuhan } \boldsymbol{M} . \\
\text { tuberculosis(+ EGCG 150 ppm) } \\
(\boldsymbol{\%})\end{array}$ \\
\cline { 2 - 3 } & $\mathbf{E M B}$ & EMB \\
\hline $10 \mathrm{ppm}$ & $100 \pm 0,000$ & $90 \pm 0,007$ \\
$5 \mathrm{ppm}$ & $90 \pm 0,007$ & $90 \pm 0,000$ \\
$2 \mathrm{ppm}$ & - & $\underline{90} \pm 0,000$ \\
$1 \mathrm{ppm}$ & $80 \pm 0,014$ & - \\
$0,5 \mathrm{ppm}$ & $70 \pm 0,007$ &
\end{tabular}

Potensi masing-masing OAT lini pertama bisa meningkat setelah dikombinasikan dengan EGCG disebabkan oleh mekanisme penghambatan pertumbuhan $M$. tuberculosis oleh OAT tersebut dengan EGCG berbeda, sehingga terjadi efek potensiasi. Mekanisme EGCG dalam menghambat pertumbuhan bakteri belum benar-benar dijelaskan. Penelitian yang dilakukan oleh Anand dkk menunjukkan bahwa komponen utama dari polifenol teh hijau, yaitu EGCG memiliki kemampuan inheren untuk menurunkan transkripsi gen host tryptophan-aspartate containing-coat protein (TACO) dalam makrofag manusia. Gen TACO tersebut telah menunjukkan peran penting pada penahanan proses pematangan fagosom yang mengandung M. tuberculosis patogen dalam makrofag. Penurunan ekspresi gen TACO oleh EGCG dibarengi dengan penghambatan hidup M. tuberculosis dalam makrofag. Berdasarkan hasil tersebut, EGCG berpotensi digunakan sebagai pencegahan infeksi tuberkulosis. ${ }^{7}$

Beberapa penelitian juga menyatakan hipotesis tentang aktivitas antimikroba dari ekstrak teh dapat terjadi karena adanya ikatan kuat antara muatan negatif dari EGCG dengan muatan positif pada lapisan lipid bilayer pada bakteri Gram-positif. Senyawa katekin berpartisi ke dalam membran lipid bilayer yang menyebabkan struktur dan fungsi sel bakteri menurun, sehingga akhirnya mengakibatkan kematian sel bakteri tersebut. ${ }^{6}$
EGCG mempunyai fungsi yang berbeda selain fungsi sebagai antimikroba, yaitu sebagai antioksidan yang juga dapat berperan menghambat pertumbuhan $M$. tuberculosis. Fatima dkk telah melakukan penelitian secara in vitro mengenai hal tersebut, dan menunjukkan bahwa karena sifat antioksidannya, EGCG dapat menghambat jalur ROS dan RNI, selain itu EGCG juga memberikan hasil yang lebih baik dalam penghambatan ekspresi gen TNF- $\alpha$ dan MTB 85B dibandingkan dengan OAT lini pertama lain. ${ }^{9,10}$

Mekanisme penghambatan dari pertumbuhan $M$. tuberculosis oleh OAT berbeda dengan EGCG yaitu, RIF dapat menghambat DNA-dependent RNA polymerase dari mikobakteri, INH dapat mengganggu sintesis asam mikolat sehingga dinding $M$. tuberculosis tidak terbentuk, PZA mengganggu energetika membran bakteri dan menghambat transportasi membran, serta EMB mengganggu biosintesis dinding sel arabinogalactan. ${ }^{15,16}$

EGCG memiliki aktivitas antituberkulosis dan dapat meningkatkan potensi OAT lini pertama (RIF, INH, PZA dan EMB). Jika terapi penyakit TB menggunakan EGCG sebagai komplemen, diharapkan dapat menurunkan dosis OAT yang digunakan, dan meminimalkan efek samping OAT tersebut serta menurunkan toksisitas OAT, sehingga terapi akan lebih efektif, serta timbulnya resistensi obat dapat dicegah dan ditangani. 


\section{KESIMPULAN}

(-)-Epigallocatechin-gallate (EGCG) memiliki aktivitas antituberkulosis dan secara potensiasi dapat meningkatkan potensi OAT lini pertama jika dikombinasikan bersama.

\section{SARAN}

Penelitian ini menyarankan adanya penelitian lebih lanjut mengenai penentuan aktivitas OAT lini pertama yang dikombinasikan dengan EGCG terhadap MDR-TB, serta penelitian mengenai penentuan regimen dosis EGCG dan teh hijau untuk terapi komplemen pasien TB sehingga terapi menjadi lebih efektif.

\section{UCAPAN TERIMA KASIH}

Penulis mengucapkan terima kasih kepada Kementerian Riset, Teknologi dan Pendidikan Tinggi atas pendanaan riset ini dan Fakultas Farmasi Universitas Airlangga Surabaya atas bantuan sarana dan prasarana selama pelaksanaan penelitian.

\section{DAFTAR RUJUKAN}

1. Global Tuberculosis Report 2013. Geneva: World Health Organization; 2013.

2. Kementerian Kesehatan Republik Indonesia. Situasi TBC di Indonesia. Diperoleh dari: https://www.tbindonesia.or.id/page/view/ 11/situasi-tbc-di-indonesia [Diakses 2019 Oktober 15].

3. World Health Organization. Multidrugresistant tuberculosis (MDR-TB) October 2013 Update. Diperoleh dari: www.who.int/tb/challenges/mdr [Diakses 2013 November 27].

4. Faustini A, Hall AJ, Perucci CA. Risk factors for multidrug resistant tuberculosis in Europe: a systematic review. Thorax. 2006 Oct;61:158-163.

5. Mulu W, Mekonnen D, Yimer M, Admassu A, Abera B. Risk factors for multidrug resistant tuberculosis patients in Amhara National Regional State. African Health Sciences. 2015
June;15(2):368-377.

6. Koech KR, Wachira FN, Ngure RM, Wanyoko JK, Bii CC, Karori SM, et al.Antimicrobial, synergistic and antioxidant activities of tea polyphenols. In: A. Méndez-Vilas, Ed.Microbial pathogens and strategies for combating them: science, technology and education. Badajoz: Formatex Research Center; 2013. p. 971-981.

7. Anand PK, Kaul D, Sharma M. Green tea polyphenol inhibits Mycobacterium tuberculosis survival within human macrophages. The International Journal of Biochemistry \& Cell Biology. 2006 Nov;38:600-609.

8. Das S, Tanwar J, Hameed S, Fatima Z. Antimicrobial potential of epigallocatechin-3-gallate(EGCG): a green tea polyphenol. Journal of Biochemical and Pharmacological Research. 2014 September;2(3):167-174.

9. Fatima $Z$, Hameed S, Islam $N$. Epigallocatechin-3-gallate(EGCG), a green tea polyphenol suppresses bacilliinducedaugmented expression of Mycobacterium tuberculosis 85Band proinflammatory TNF- $\alpha$ in human monocytes. International Journal of Scientific and Research Publications. 2012 February;2(2):1-6.

10. Fatima Z, Hameed S, Islam N. Green tea polyphenol (EGCG) is a better inhibitor of TNF- $\alpha$ and MTB 85B antigen in human monocytes than known antioxidants and antibiotics. The Journal of Infectious Diseases. 2013 March;112:131-137.

11. Peñuelas-Urquides $K$, Villarreal-Treviño L, Silva-Ramírez B, RivadeneyraEspinoza L, Said-Fernández S, Bermúdez de León M. Measuring of Mycobacterium tuberculosis growth. A correlation of the optical measurements with colony forming units. Brazilian Journal of Microbiology. 2013 Mei;44(1):287-290.

12. Chen C, Song F, Wang Q, Abdel-Mageed $\mathrm{WM}$, Guo $\mathrm{H}, \mathrm{Fu} \mathrm{C}$, et al. A marinederived Streptomyces sp. MS449 produces highyield of actinomycin X2 and actinomycin $\mathrm{D}$ with potent antituberculosis activity. Applied Microbiology and Biotechnology. 2012 April;95:919-927.

13. Klancnik A, Piskernik S, Jersek B, 
Mozina SS. Evaluation of diffusion and dilution methods to determine the antibacterial activity of plant extracts. Journal of Microbiological Methods. 2010 May;81(2):121-126.

14. Gupta R, Thakur B, Singh P, Singh HB, Sharma VD, Katoch VM, et al. Antituberculosis activity of selected medicinal plants against multidrug resistant Mycobacterium tuberculosis isolates. Indian Journal of Medical Research. 2010
June;131:809-813.

15. Sulistia GG. Farmakologi dan Terapi, Edisi 5. Jakarta: Balai Penerbit FKUI; 2007.

16. Silva PEAD, Palomino JC. Molecular basis and mechanisms of drug resistance in M. tuberculosis: classical and new drugs. Journal of Antimicrobial Chemotherapy. 2011 May;66:1417-1430. 